\title{
Sphenoid Bone Fibrous Dysplasia Detected Incidentally on Bone Scintigraphy by the Contribution of SPECT/CT Hybrid Imaging
}

\author{
SPECT/BT Hibrid Görüntülemenin Katkısıyla Kemik Sintigrafısinde Tesadüfen Saptanan Sfenoid \\ Kemik Fibröz Displazisi
}

\author{
(D) Hüseyin Şan', (D) Kürşat Okuyucu2, (D) Ali Ozan Öner³, (D) Özdeş Emer², (D) Alper Özgür Karaçalıoğlu² \\ IKarabük Training and Research Hospital, Clinic of Nuclear Medicine, Karabük, Turkey \\ 2Gülhane Training and Research Hospital, Clinic of Nuclear Medicine, Ankara, Turkey \\ ${ }^{3}$ Afyon Kocatepe University Faculty of Medicine, Department of Nuclear Medicine, Afyon, Turkey
}

\begin{abstract}
Fibrous dysplasia (FD) is a benign fibroosseous bone disorder. It has poliostotic and monostotic patterns. Monostotic FD is frequently asymptomatic and is usually discovered incidentally by radiologic imaging performed for other reasons. Bone scintigraphy is valuable for identifying disease extent. Craniofacial FD (CFD) is a form of the disease where lesions are limited to contiguous bones of the craniofacial skeleton. We presented a case with monostotic CFD who was detected incidentally on bone scintigraphy single-photon emission computed tomography/computerized tomography while being investigated for inflammatory arthropaties.

Keywords: Craniofacial fibrous dysplasia, technetium-99m-methylene diphosphonate bone scintigraphy, single-photon emission computed tomography/computed tomography
\end{abstract}

\section{Öz}

Fibröz displazi (FD) kemiklerin iyi huylu bir fibroosseöz bozukluğudur. Poliyostatik ve monostatik formları vardır. Monostatik FD sıklıkla asemptomatiktir ve genellikle radyolojik görüntülerde tesadüfen fark edilir. Kemik sintigrafisi hastalığın yayılımını belirlemede değerlidir. Kraniyofasiyal FD (CFD) hastalığın kraniyofasiyal iskeletin kemiklerine sınırlı olduğu bir formudur. Enflamatuvar artropati yönünden araştırılırken tesadüfen kemik sintigrafisinde tek-foton emisyon bilgisayarlı tomografi/ bilgisayarlı tomografi ile tespit edilen bir monostatik CFD olgusunu takdim ediyoruz.

Anahtar kelimeler: Kraniyofasiyal fibröz displazi, teknesyum-99m-metilen difosfonat kemik sintigrafisi, tek-foton emisyon bilgisayarlı tomografi/bilgisayarlı tomografi

Address for Correspondence: Kürşat Okuyucu MD, Gülhane Training and Research Hospital, Clinic of Nuclear Medicine, Ankara, Turkey Phone: +90 3123044808 E-mail: k.okuyucu@yahoo.com ORCID ID: orcid.org/0000-0002-4481-9531

Received: 15.04.2016 Accepted: 10.08.2017

${ }^{\circ}$ Copyright 2018 by Turkish Society of Nuclear Medicine

Molecular Imaging and Radionuclide Therapy published by Galenos Yayınevi. 
A

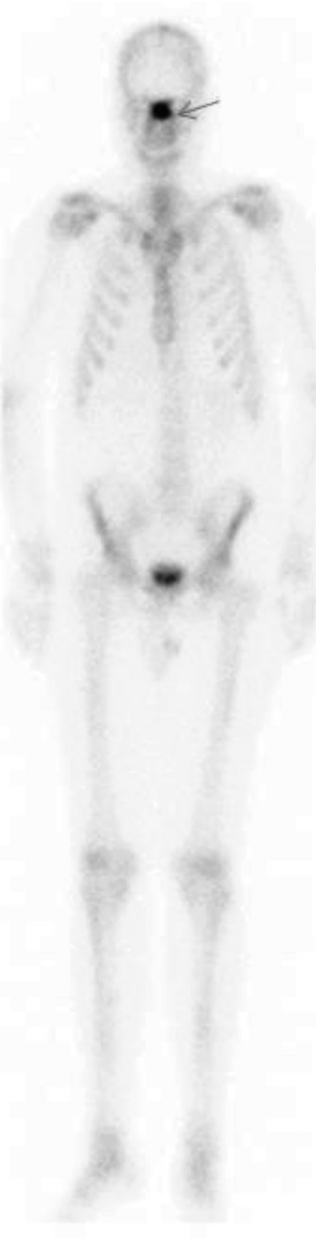

B

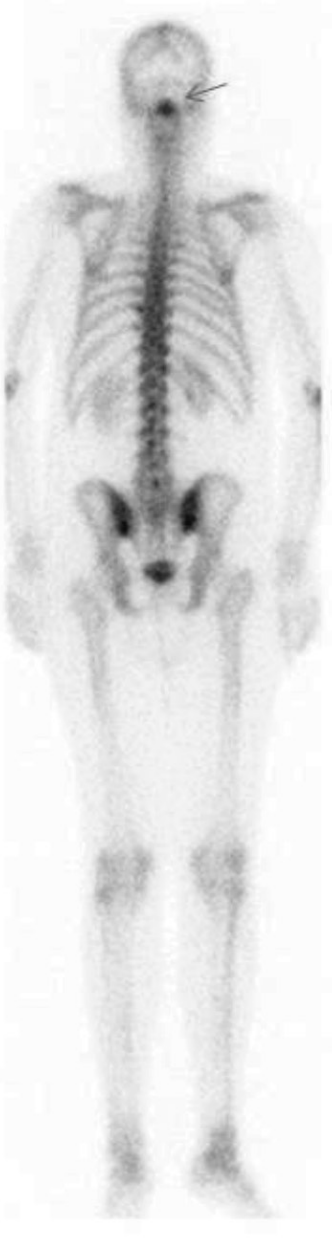

C
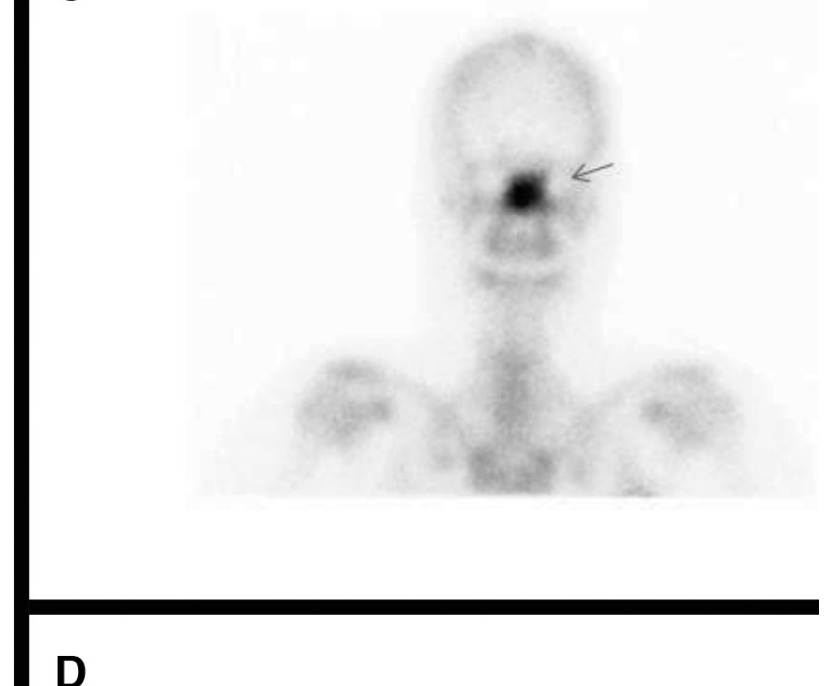

D

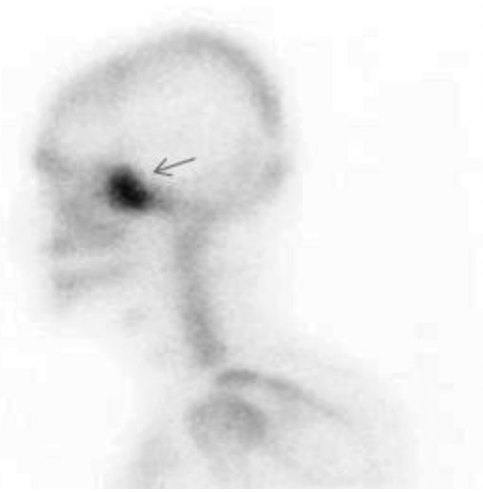

Figure 1. Anterior whole-body (A), posterior whole-body (B), anterior head spot (C), left lateral head spot (D) late static planar images of technetium (Tc)-99m-methylene diphosphonate (MDP) bone scintigraphy showing uptake in the middle facial region (arrows).

Fibrous dysplasia (FD) is a benign disorder of the bone in which there is developmental arrest of all components of normal bone (1). The lesions progressively replace the medullary cavity (2). Long bones, ribs, craniofacial bones and pelvis are the most common sites of skeletal involvement (3). It has been reported that the monostotic form constitute $70 \%$ of cases while $30 \%$ are polyostotic (4). Craniofacial FD (CFD) is a form of the disease where lesions are limited to contiguous bones of the craniofacial skeleton $(5,6)$. Craniofacial involvement is present in $10-27 \%$ of monostotic cases and $50 \%$ of polyostotic ones $(7,8)$. CFD without involvement of bones out of the cranium can not be easily described as monostotic because of the potential adjoining involvement of cranial bones $(6,9)$.

A 20-year-old male with back pain was investigated for seronegative spondylarthropathy. In order to demonstrate any inflammatory joint involvement, a three-phase Tc-99m-MDP bone scintigraphy was requested. Although perfusion and blood pool phases were normal, there was intense MDP uptake in the middle facial region on late static phase whole-body images. 


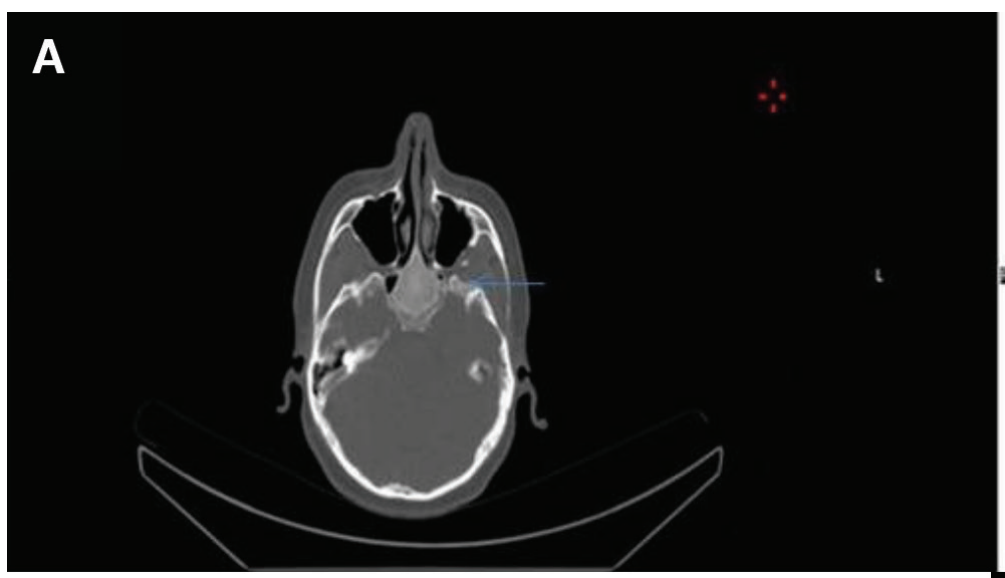

B

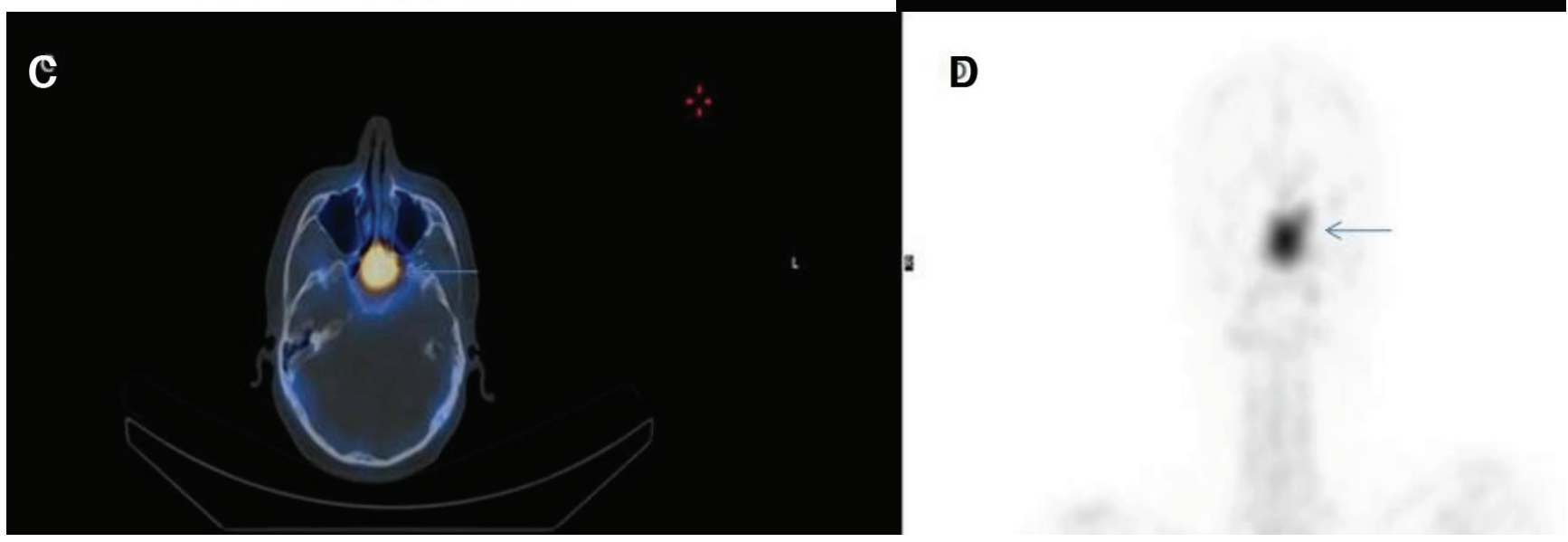

Figure 2. Computerized tomography (CT) (A), single-photon emission CT (SPECT) (B), fusion (C), maximum intensity projection (D) images on SPECT/ CT hybrid imaging of Tc-99m-MDP bone scintigraphy that localize and spot the uptake on planar images in the sphenoid bone (arrows).

For the exact localization of this abnormal incidental finding, SPECT/CT hybrid imaging was performed. This accumulation was situated at and confined to a well-marginated, ground-glass opacity in the corpus of the sphenoid bone on CT component (Figure 2). The lesion was resembling a benign bone disorder (suggestive of monostotic FD). Magnetic resonance imaging (MRI) was requested to differentiate it from other benign bone pathologies that confirmed the diagnosis of FD.

$\mathrm{CT}$ is the best technique for depicting lesion extent, cortical boundary and homogeneity of the poorly mineralized lesion (10). Well margination, hazy ground-glass opacity and contrast enhancement are characteristic features of FD on CT $(10,11)$. MRI is quite sensitive for detecting FD and provides complementary information to CT (12).

Although bone scintigraphy has low specificity for FD, it has a valuable role on identifying disease extent at initial presentation due to its high sensitivity $(10,11)$. Despite its high capability of lesion detection, determining exact lesion location by this method is problematic especially for contiguous bones of the craniofacial region. CT and MRI are good options to overcome this obstacle easily, by providing accurate anatomical detail. On the other hand, without a whole-body imaging which is not practical by CT or MRI, whether CFD is polyostotic or not can not be clarified. For this reason, existence of any lesion in other parts of the body other than the craniofacial region should be clearly depicted. A whole-body bone scintigraphy at a single session and an additional SPECT/CT, which provides both anatomical and functional data, will be sufficient to elucidate this issue. 


\section{Ethics}

Informed Consent: Consent form was filled out by all participants.

Peer-review: Externally peer-reviewed.

\section{Authorship Contributions}

Surgical and Medical Practices: H.Ş., K.O., Ö.E., A.Ö.K., A.O.Ö., Concept: H.Ş., K.O., Design: H.Ş., K.O., Ö.E., Data Collection or Processing: H.Ş., Analysis or Interpretation: A.Ö.K., Literature Search: A.O.Ö., Writing: H.Ş., K.O.

Conflict of Interest: No conflict of interest was declared by the authors.

Financial Disclosure: The authors declared that this study received no financial support.

\section{References}

1. Kumar V, Abbas AK, Aster JC. Robbins \& Cotran Pathologic Basis of Disease, 9th ed. 2015;1408.

2. Elgazzar AH. Synopsis of Pathophysiology in Nuclear Medicine. Springer International Publishing 2014;357.

3. Harisankar CN, Bhattacharya A, Bhadada SK, Kamaleshwaran KK, Mittal BR. An interesting case of polyostotic fibrous dysplasia: The "pirate sign" evaluated with Tc-99m methylene diphosphonate single-photon emission computed tomography/ computerized tomography. Indian J Nucl Med 2011;26:40-41.

4. Schlumberger HG. Fibrous dysplasia of single bones (monostatic fibrous dysplasia). Mil Surg 1946;99:504-527.

5. Daves ML, Yardley JH. Fibrous dysplasia of bone. Am J Med Sci 1957;234:590-606.

6. Menon S, Venkatswamy S, Ramu V, Banu K, Ehtaih S, Kashyap VM. Craniofacial fibrous dysplasia: Surgery and literature review. Ann Maxillofac Surg 2013;3:66-71.

7. Harris WH, Dudley HR Jr, Barry RJ. The natural history of fibrous dysplasia: An orthopedic pathological and roentgenographic study. J Bone Joint Surg 1962;44:207-233.

8. Owlia F, Karbassi MH. Craniofacial polyostotic fibrous dysplasia: A rare case. Dent Res J (Isfahan) 2014;11:518-521.

9. Kim DD, Ghali GE, Wright JM, Edwards SP. Surgical treatment of giant fibrous dysplasia of the mandible with concomitant craniofacial involvement. J Oral Maxillofac Surg 2012;70:102-118.

10. Leeds N, Seaman WB. Fibrous dysplasia of the skull and its differential diagnosis. Radiology 1962;78:570-582.

11. Zhibin $Y$, Quanyong L, Libo C, Jun Z, Hankui L, Jifang Z, Ruisen Z. The role of radionuclide bone scintigraphy in fibrous dysplasia of bone. Clin Nucl Med 2004;29:177-180.

12. Jee WH, Choi KH, Choe BY, Park JM, Shinn KS. Fibrous dysplasia: MR imaging characteristics with radiopathologic correlation. AJR Am J Roentgenol 1996;167:1523-1527. 